\title{
Nigerian National Population and Housing Census and Sustainable Development: Issues at Stake
}

\section{Isah Shehu Mohammed ${ }^{1,}{ }^{*}$ Muhammad Fuad Othman ${ }^{2}$, Nazariah Binti Osman ${ }^{3}$}

${ }^{1}$ General Studies Department, School of General Studies,

The Federal Polytechnic, Bauchi, Bauchi State, NIGERIA

${ }^{2,3}$ School of International Studies, College of Law, Government and International Studies,

Universiti Utara Malaysia, Sintok, Kedah, 06010, MALAYSIA

*Corresponding Author

DOI: https://doi.org/10.30880/jts.2018.11.01.003

Received 00 Month 2000; Accepted 01 Month 2000; Available online 30th June 2019

\begin{abstract}
This study is about conducting population and housing census and sustainable development in Nigeria. The main objectives are to identify the critical issues in conducting census exercise for the federation of Nigeria. Conducting decennial population and housing census, although being phased out, has especially in developing states, remained the main source of quality demographic data. In Nigeria, such censuses conducted have not in her history, been only the crucial source of statistical data for socio-economic, political and sustainable development, but also problematic, sensitive, divisive, expensive, and controversial. Sustainable development cannot be achieved with mere census figures unless they are valid and reliable for planning and implementation, no matter how abundant human and material resources may be available and committed to such. Nigeria's conduct of decennial census has been missed since the last one conducted in 2006 and up to the early part of 2019, after officially shifting the exercise three times. This study used secondary sources of data and historical method of data analysis to identify the major issues confronting future census exercise in Nigeria. For any future census to be conducted in Nigeria, there are major issues/challenges of inaccessibility to some areas due to militancy in the Niger Delta; renewed Boko Haram insurgency, resultant effects of ethno-religious conflicts; agitations for re-structuring Nigeria, internally displaced persons and camps, proper and timely sourcing of funding, proper management/administration of ethno-religious issues involving sensitive questions, recruitment/appointment scams of census officials and enumerators, among others. The article recommended shift from the traditional and decennial to administrative census; intensive and extensive enlightenment, involvement of traditional and communities' leaders, among others. The study is very significant at this time of dilemma in which the Nigerian state has fallen with shortages of funds, insecurity in most parts of Nigeria, increased manipulation of ethnicity, religions, and politics for selfish interests, and a struggle for resource control and allocation by Nigerians.
\end{abstract}

Keywords: census, Nigeria, issues, population, sustainable development, statistics

\section{Introduction}

Nigeria is indeed geographically very big, populous, heterogeneous and rich in human and material resources. It is also the world's largest single, and most populous black nation; the most populous in Africa with over $25 \%$ of the continent's total population. The abundance of both human and material resources has, similarly, given Nigeria many advantages over all the African and many other states across the world. Nigeria, is most influential in Africa and the rest of the world because of her population size - over 193.3m people (National Bureau of Statistics, NBS, 2018; 
Oyeshola, 2008: x). Therefore, the most strategic resource for Nigeria is her population, which is very essential to every states' socio-economic, political, security and sustainable development. Like in many other states, however, knowing how many people are there in Nigeria over a period of time has remained very challenging to its socio-societal, security, political, economic pursuits. As such, over time and from pre-independence to date, several heads and housing counts have been conducted in order to obtain the total number of persons in Nigeria over given periods of time. Those were particularly important as no meaningful planning and development could be made and successfully implemented without knowing who and how many to plan for, what to plan and at what time? Without these, no sustainable development can be achieved. In fact, the more attempts are made without reliable population statistics, the more the resources (human and material) are wasted and developmental efforts distorted. The importance of conducting successful and reliable census in the Nigerian state cannot, therefore, be over-emphasised.

\subsection{Statement of the Research Problem}

Nigeria's drive to sustainable development has neither been easy nor working well (Orewa (1997: xi), especially in relation to population and housing census conduct. Through the annals of history, Nigeria has had several censuses conducted from pre to post independence era, but as Gupte (1994:44) notes, "the question of population and politics is especially thorny in Nigeria". Controversy, cancellations, unhealthy politics and rivalry, political instability and military intervention had in the past, all resulted from the conducts of some these censuses. By Nigeria's convention and United Nations standard, census exercise is supposed to be done decennial (with the latest supposed to be conducted in the year 2016). However, due to political, technical, social, other logistics and peculiar problems, the 2016 count could not be held, but shifted to the year 2018 and later 2019. In addition to those problems above, there are new and more challenges evidently faced in the proposed 2019 census. The conduct of censuses has remained resource intensive as Nigeria has also clings to the decennial census, which is the most expensive, unreliable and now being phased out by many states. Even the decennial conducts have in Nigeria, not been regular in addition to the other numerous problems. Nigeria is at present challenged by shortages of funds which affect the timely preparations and necessitated re-scheduling/shift of the count from 2016 to the year 2019. Census has been an instrument used by politicians in Nigeria to achieve their personal ends (Okafor, 2015). This especially with the current agitation and politics of restructuring Nigeria, are bound to affect the census and its outcome, just as politicians, regions, states are likely to try all they can to manipulate/falsify the figures as its conduct for political, economic, ethno-religious and other advantages (Adele, 2009). It is also manipulated to determine who gets what in Nigeria (Idike \& Eme, 2015).

Other problems such as Boko Haram insurgency, cattle rustling and kidnappings, Fulani/herdsmen-farmers conflict, which have devastated the North-East, North Central and North Western states of Adamawa, Borno, Yobe, Benue, Nassarawa, Plateau, Taraba, Zamfara threaten a credible exercise as the areas are mainly inaccessible or deserted (Mohammed, 2018; Mohammed \& Aisha, 2018). Similarly, there are at the moment, more and very stringent challenges for unity and cohesion of Nigerian state as a result of renewed militancy in the Niger Delta, secession threats from the South-East Igbo groups and clamour for restructuring the Nigerian state and federalism mainly from the Western and Eastern parts of the country; unhealthy regional and ethno-religious rivalry and antagonism (Shehu, Othman \& Osman, 2017), which all have bearings on the success of the census exercise.

Nigeria's sustainable development which is indispensable to conduct of a credible census exercise is threatened by these major issues which if not fully and timely addressed, would evidently undermine the success and credibility of the forthcoming population and housing census exercise. This will not only retard development but also affect all other sectors and the lives of Nigerians, with overall effects on national security, development, stability and sustainability.

\subsection{Objectives of the Study}

Conducting a credible population and housing census for sustainable development is not an easy task as many benefits are derived from its result when reliably obtained, analysed and properly managed. In line with that, the major objectives of this study are to trace the history of conducting population and housing census in Nigeria; identify the various areas of general and peculiar challenges to the previous, and especially the forthcoming national housing and population census exercise; identify other areas for strengthening the success of such exercise; strengthen the need for working with the valid and reliable findings of the census exercise for better resource use and decisions to achieve sustainable development; debunk the notion that Nigeria has too many people and emphasise the need to make efficient use of both human and material resources for a sustainable development; identify the factors responsible for nonsustainability of development in Nigeria; and identify other factors responsible for the problems associated with population in Nigeria and give recommendations on how to arrive at a popular, credible and dependable census exercise for Nigeria.

\subsection{Methodology}

This study used secondary sources of data and applied historical method of data analysis to draw the issues in sustainable development and conduct of population and housing census in Nigeria. The data was sourced from secondary sources and the current realities of affairs in Nigeria, characterized by insurgency, ethno-religious conflicts 
and threats to Nigerian unity. The study took cognizance of the past historical trends of conducting population and housing census in Nigeria, the controversies, challenges, legal battles and cancellations, especially the 1962/63 and 1973 census exercises. Various accounts of the past census were therefore used in the analysis of the study.

\subsection{Background of Nigerian State, Societies, Population and Housing Census Conduct}

The name Nigeria was used first and formally by the Colonial Masters in January, 1897 and 1914 respectively. The area/name 'Nigeria' (coined from Niger and Areas) was in not in any form a single and or united political entity until January 1, 1914 when the British Colonial masters decided to make one and a whole out of the many political, historical, religious, economic and socio-cultural entities that were for long before the British colonial domination and control in 1861, separate and independent of one another. The British colonial masters united the numerous areas that later became Nigeria together in order to satisfy their imperial, economic, political and administrative interests. However, the history of contacts with the peoples around what later became Nigeria with Europeans through the Atlantic Ocean dates back to 1470 when the Portuguese arrived first coast (Kirk-Greene, 1971; Kwanashie, 2002; Uwuche, Bing, Derrick, Owino \& Matatu, 1991:1448).

It was, however, the January 1, 1914 amalgamation of the areas that brought different Kingdoms, Caliphate, Empires and other small states and acephalous societies together to make up Nigeria, but the consent, opinion and considerations of the various areas and peoples were in actually not sought, but were over-ruled by the British imperial and colonial interests (Nnoli, 1978; Falola, Mahdi, Uhomoibhi \& Anyanwu, 1991:113; Amuwo, Agbale, Suberu \& Herault, 1998:15; Oyovbaire, 1979). Nigeria's people are so diverse that it is composed of three of the five African language families - Nilo-Saharan, Niger-Congo and Afro-Asiatic (Whitaker, 1970:597). Before the Colonial conquest, the Northern part was composed of Muslims (who received Islam from trans Sahara trade routes - Borno, Kano, Katsina, Agadez [Niger], Khartoum [Sudan], Timbuktu [Mali], Tarabulus [Libya], Misra [Egypt], other traditional religions and also Acephalous societies. The religion of Christianity (which was received from the trans-Atlantic) was later introduced alongside colonial domination and rule in the Northern and Southern Regions (Falola \& Heaton, 2008; Young, 1976:461).

With Colonialism, it took the British over 40 years to establish firm control over all the areas around the two major rivers of the Niger and Benue and by 1900, the British Majesty's Colonial Government paid the Royal Niger Company (RNC), which had earlier claimed and was in control of the areas, a compensation of $£ 450,000 ; £ 115$, 000; and accepted another debt of $£ 250,000$ (Ajayi, 2009:9). Nigeria finally got her independence from Britain on October 1, 1960 after colonial domination and rule for almost 100 years. Geographically, Nigeria has a total of $923,768 \mathrm{sq} . \mathrm{km}$ with about 730,885 sq. km of arable land which is largely located in the Northern part. It also has a coastline of about $774 \mathrm{Km}$ and a total of $4775 \mathrm{~km}$ long borderline (Ate \& Akinterinwa, 1992:31). The Northern region has bigger land mass, population and solid minerals with about 255,700 square miles when compared with the Southern region 76,700 square miles. Nigeria is very rich in both human and material resources and thus very fortunate among the comity of nations, and also enjoying strategic geographical location within the African continent and sub-region (Irukwu, 2005:189). Similarly, Nigeria uses only $44 \%$ of her land for permanent pasture, $12 \%$ for forest and wood, $3 \%$ for permanent crops and $8 \%$ for other purposes. While $75 \%$ of Nigeria's total land is fertile, only about $14 \%$ is being used for such purposes (Oyeshola, 2008:165).

The Popular River Niger is Nigeria's major and most lengthy river from the Sierra-Leonean Mountains, then NorthWest Nigeria through French Sudan to the Gulf of Guinea (Coleman \& Roseberg, 1970). The oil-rich Niger Delta Region covers an area of 28, 000 sq. km, mangrove swamp of 300 miles and lies in the Southern part of Nigeria and River Niger. During the pre-independence and early post independence periods, three dominant political parties (Action Group - AG, Northern Peoples' Congress - NPC and National Convention of Nigerian Citizens' - NCNC, each of the three respective Regions of West, North and East) with ethno-regional substance and backgrounds characterised and dominated Nigeria's politics and governance. Nigeria has been practicing federalism from the pre-independence period through the independence (except for periods of military) up to date. It assumed federalism first with three (3) strong Regions in 1954-63 (East, North and West), four (4) strong Regions from1963-66 (East, North, West and Mid-West), twelve (12) States from 1967-76, nineteen (19) States from 1976-87, twenty-one (21) States from 1987-91, thirty (30) States from 1991-96, and thirty-six (36) States from 1996-date with the Federal Government being constitutionally more powerful, than the States and Local Governments.

Census in the history of what much later became united Nigeria was first conducted in the year 1866, but for and only within the Colony of Lagos, as Nigeria was not then formed into a single entity (Iwuoha, 2017). There were also censuses conducted (for Lagos Colony only) in the years of 1871, 1881 and 1901 with intervals of ten (10) years each. However, ten (10) years later, in 1911, another census which also covered Southern Protectorate of Niger together with Lagos on one hand and another on the Northern Protectorate of Niger was conducted. The formation of a single entity (Nigeria) in January, 1914 brought a remarkable development concerning census exercise in Nigeria as the Colonial Government established The Nigerian Census Ordinance, 1917, thereby enabling the colonial government to successfully conduct the first Nigerian National Census in 1921. Thereafter, Censuses were conducted decennially, except the 1940's when the Second World War was being fought and much attention shifted to that. In the 1931 census results, there were about $19 \mathrm{~m}$ people in Nigeria; the 1952/3 census had about total a of $30.4 \mathrm{~m}$ persons; then the 1962/3 
(most controversial census), which had 55.7m persons (Paden, 1986: 428; Kurfi, 2004:169-70; Mainasara, 1982:41; Shagari, 2001:109; Ayida, 1987:120; Uwuche, et. al., 1991:1462). The General Gowon's regime census was cancelled by the Murtala/Obasanjo regime due to the controversies which trailed it. Thus the 1987 Political Bureau's lamentation that :

An overview of the Nigerian political experience since independence in 1960 shows clearly that among the many issues that have created great anxiety and brought the country to the brink of collapse has been the attempt at obtaining an accurate count of the country's population. The potency of the issue as a source of confusion and a national discord is underscored by the fact that attempts made by civilians (1962-1963) and the military (1973) were greeted with the same degree of cynicism, suspicion and controversies and had to be cancelled.

The supposed 1981 census exercised during President Shehu Shagari's regime was skipped until in ten years after in 1991 when another Census exercise was carried out during the General Babangida regime which revealed that there were 88, 992, 220 persons in Nigeria, the last in the series of census exercises held in Nigeria was that conducted in the year 2006 with figures of 140, 003, 542 persons in Nigeria (71,709, 859 males and 68, 293, 683 females), with 2.9\% annual growth rate and $37.7 \%$ and $62.3 \%$ of urban and rural dwellers respectively (Iwuoha, 2017).

The post 2006 census projections by the National Population Commission has $3.2 \%$ annual increase/growth rate with Kano, Lagos and Kaduna States as most populous, while Bayelsa, Nassarawa and Ebonyi respectively as the least populated States. Currently, Nigeria has an overall population of about 193.3m (Elaigwu \& Garba in Chakrabarti \& Srivastava, 2015:82; NBS, 2018). The international and conventional period of conducting a census decennially (after every 10 years), has historically been missed by Nigeria in the years of 1941, 1981, 2001 and that of 2016 (now shifted to 2019).

\section{Literature Review}

A robust literature is available on population, statistics and sustainable development, some of which have concentrated on population growth and explosion, problems, patterns of population distribution and population and sustainable development, while others worked on population and environmental issues. The word 'census' was derived from the Latin language and word 'censere' which means to 'assess' thus the act of gathering information on characteristics, sizes and issues related to population. With that, he defined census as the act and method of collecting population and related data by counting and assessing individuals in a defined area, at specified period of time and backed by state laws. The United Nations Organisation (1958:3) defined population census as the complete process of collecting, compiling and publishing of demographic, economic and social data pertaining all persons in a country at a specified time and delimited territory.

The history of conducting population census is traced to the United States, Canada and Australia in the years 1790, 1871 and 1881 respectively. Moss \& Rathbone (1975:3) note that population is one of the most significant variables in life, hence it is important to know how many people are there and dealt with, their rates of increase and decrease, ages, sex, density and epidemics. Himmelfarb \& Baras (1978:3) emphasise that concerns about population, its growth and size are very old in human history. Therefore, Lutz (1994:7-18) and Nwaimo (2009:620) not only stress the importance of the census and reliable projections on socio-economic policies and programmes in every state, but place emphasis on the its reliability and further maintain that it is vital to socio-economic and political planning and development of every state, as it helps to plan and monitor developmental goals. On the other hand, sustainable development for Brundtland Commission (as cited in Uchegbu 1998), involves a process of change in exploitation and the harnessing of human and material resources, proper technological development decisions and institutional changes in current and future potentials to satisfy state and societal needs and targets, while at the same time achieving a balance between needs and proper management and preservation of resources for future needs. Som (2008) maintains that planning is the systematic study and analysis of likely lines of action on a programme, policy or course of action. Therefore, planning is also a process by which major objectives, policies and strategies that govern the acquisition and usage of resources to achieve objectives are made (Hosh, 1993). Such planning rely on statistics, which are generally used to make provisions, forecasts for population and in both public and private sectors. Kruskal (as cited in Fairley \& Mosteller, 1877:3) maintains that a government works with better and reliable and an impartial data, and some of the information required by its citizens can best be provided by the government, while some of the details are provided and specifically on population.

Mason, Losos and Singer (2011:1165) observe that there are three characteristics of a population as: population range (the area occupied by the population and on which it occurs); pattern of spacing individuals and the range of such spaces in the population; and how the population increases or decreases over specific time. Accordingly, Ogunjuyigbe (as cited in Ogunbameru \& Rotimi, 2006: 283), notes that human population modifies its environment, the environment also modifies the population, and population distribution depends on an environment and the density of that same population. Starr, Evers and Starr (2010:326) also observe that the quantity of resources in an environment affects the population size that it can sustain, and a population occupying an environment with limited resources undergoes logistic growth. It is also maintained by Miller \& Spoolman (2008:123 \& 137) that half of the world's population lives in the urban areas and so the problems of the population explosion, pressure and accommodation are mainly encountered in urban areas just as housing and accommodation problem in Nigeria is mainly in the urban areas due to 
rapid urbanisation and high population growth (Adeniyi, 1981). For Nigeria, the carrying capacity of her environment in relation to its population and resources has not been exhausted, despite the large population, but it is rather under utilised (resource-population analysis in Starr, et al., 2010:327).

Miller \& Spoolman (2008:124-6) have observed that during the last 200 years, human population has all over the world increased rapidly due to man's ability to expand to new and diverse habitat, climate zones, improved agricultural services and output, improved sanitation and the development of antibiotics and vaccines, which helped greatly to limit diseases. The growth of world population is, however, unevenly distributed and expected to increase from 6.7 billion in 2007 to about 9.2 billion by the year 2050 with more than $82 \%$ of the world's population in developing countries. Many also argue that the world is over populated/not over-populated; others maintain that developing countries constitute the global problem of population; and yet to some others, the developed countries are the problem for the fact that they have high resource consumption (Miller, 2007:171). In the same vein, Weller and Bouvier (1992:46) have asserted that stopping the world population growth alone would not solve the problem of population explosion, but that the wealthy nations would have to share the population and resources with the poorer ones, with improvement in the distribution system, better enforcement of existing laws, and development of greater social conscience. Similarly, Starr et al. (2010:326) and Miller (2007:173-4) have noted that birth, death and movement rates of individuals affect the size of the population as it increases due to more birth and immigration, and also reduces as a result of death and emigration. While the factors that limit population growth are of two categories - Density Dependent Factors (DDF), which decrease or increase birth rate and also worsen with crowding of people, e.g., competition for resources and diseases; and Density Independent Factors (DIF), which also decrease births or increase deaths, but are not influenced by crowding of people, e.g., fire, storms, earthquakes and other natural calamities that affect both crowded and uncrowded populations.

Reverend Malthus Thomas is the most popular theorist on population and although his essay titled 'An Essay on the Principle of Population' written in 1798 was much more centred on population rise, food and standard of living, his work is still used as a background in population. Malthus had maintained that population tends to increase at a constant geometric rate of $2,4,8,16,32,62,128,256 \ldots \ldots$. However, food production and output will only increase at a constant Arithmetic rate of 1, 2, 3, 4, 5, 6 ... (Samuelson \& Nordhaus, 2005:362; Lipsey \& Chrystal, 1995:652; McConnel, 1987:426). It has, however, been argued and proved that Malthusian Theory on the population had little or no impact on the industrially developed nations as it has in and on developing countries. It is maintained that in developed countries, population has been growing, but standard of living is still rising, rather than falling and noted that the theory failed to envisage industrial revolution and technological advancement adding that population rise is a mixed blessing in relation to growth (Lipsey \& Chrystal, 1995:653; McConnell, 1987:426-7). Similarly, McEarchern (2005:563) has observed that the Sub-Saharan African countries are the poorest in the world, but yet have the fastest population growth rate that exceed their Gross Domestic Production (GDP) growth, which also means an increase in population size, but with falling standard of living. It is also observed that rapid population growth is a fundamental problem of economic development and decried that it specifically causes negative GDP growth rate in developing countries. The population of industrialised nations has become stable, but that of developing countries is skyrocketing while about $97 \%$ of the world's total population growth between now and the year 2050 is expected to occur in developing countries and total of world population is expected to then reach 10bn people (Ross, Forsyth \& Huq, 2009:365-73; Miller, 2007:171; Lipsey \& Chrystal, 1995:652-3).

Thompson and Turk (2007:14 \& 16) have also observe that globally, man is currently challenged by three major trends as: large and continuing increase in population; reduction in extreme poverty; pollution and increased pressure on the available resources on earth, and further note that only about $20 \%$ of the world's total population lives where there are efficient life amenities (Water, sewage, sanitation and health care), and those are mostly found in developed and industrialised countries. In the same vein, developing countries have more cases of rural-urban migration (Miller $\&$ Spoolman, 2008:137). McConnell (1987:4756) also observes that an ecological system that can only accommodate 50100 million people will begin to break down under pressure if it comes to or, for example, have 200-300 million people under the same ecosystem. Thus Thompson and Turk (2007:16) quote Professor Diamond, who maintained that humanity is now in a 'horse race'. One horse, representing increased human consumption and resource depletion, while the other horse gallops to healthy life, happiness and a sustainable society.

In relation to that, the population pressure in Sub-Saharan Africa has led to over planting and grazing which have altogether also resulted in soil erosion, drought and widespread famine (McConnell, 1987: 427). Additionally, many African, South America and Asian countries have rapid growth of and much population problems and thereby find it difficult to raise their living standards, which is contrary to the trend in advanced nations, where there is growing population and at the same time rising standards of living. Similarly, population growth in developing countries has risen on since 1980 with an average yearly increase of $2.0 \%$ above the population growth of developed countries (McEarchern, 1994:562; Lipsey \& Chrystal, 1995: 653). In the same vein, population growth in developing countries, such as Nigeria, is difficult to control through government policies because social values place emphasis on families' sizes with children, who are also seen as a source of economic and social security (McConnell, 1987: 427); McEarchern, 1994:562). 
Population control, especially (birth) in developing countries is also seen as anti-religious, anti-privacy, breach against personal freedom, while it is politically seen as genocide in order to check population and reduce its political power (Miller, 2007:171). On the other hand, population growth is not and would not be a problem for any country so long as socio-economic adjustments are being appropriately made as emphasized by the World Bank (1984:144). In support of the World Bank's argument, Simon (1981:3-4) has also submitted that population growth and control with multi-faceted consequences are some of the major challenges of the present age and is a responsibility on all (Allison, 1970:7). It is true that there is a problem of population all over the world, but the main issue, not that there are just too many people, but others must support some/others before they also begin to in turn support some others well-being.

\subsection{Population, Housing Census and Sustainable Development in Nigeria}

Census and sustainable development are increasingly interdependent as more scholars have shifted attention to sustainable development, which cannot be achieved without reliable census figures and in relation to the proper management of both the environment and resources. Thus Oyeshola (2008:163) sees sustainable development as equitable distribution and increase in real income, improved education, more access to resources/increase in health care and nutrition and more freedom and security to citizens. Lele (1991:607-621) defines sustainable development as the new ways of life and approach to socio-economic activities of various societies (both rich and the poor), which are compatible with preservation of their environments. Sustainable development is threatened by the gravitation of economies towards stationery rate; massive and growing resource input, which are needed to raise income and standard of living; and depletion of the world's resources on which growth depends; and climate change, which also wreck the resources (Ross, et. al., 2009:286-7). Development is indispensable to planning and while development has to do with design, implementation and evaluation of various aspects related to it in order to achieve desired levels, every country's well-being and prosperity is determined by its development which is tied to the exploitation and harnessing of human and material resources. Oyeshola (2008:162) has stated that sustainable development implies three primary factors economic, social and environmental which envisage the ability to produce goods and services, on a continuing basis and under a manageable economy without jeopardising sectoral balances of economic activities of a country; maintaining stable resource bases and avoiding over exploitation of renewable resources and depletion of nonrenewable resources; and achieving equitable distribution, adequate provision of social services (health, education), gender equity, political participation, transparency and accountability.

One of the major problems faced today all over the world as far as population is concerned is that of sustainable development alongside population growth, especially in urban areas as most of the world population growth occur in the already heavily populated areas, where there are no adequate facilities to support the rapidly growing population (Miller \& Spoolman, 2008:123-5).

Similarly, the fundamental objective of conducting population and housing census all over the world is also to set forth plans for development which is targeted to be achieved and sustained. Statistics, figures, facts and forecasts are, therefore, made, analysed, documented, used and also followed up as working plans in order to attain the desired level of development. However, it is not only the issue of development that matters, but also sustainability of same, which according to Peterside, Bassey \& Goyo (2010: xxiv), is threatened by poor resources management, limited civil society involvement, lack of accountability, public participation and over bearing state power. The issues of sustainable development in Nigeria bother around efficient management of human and material resources, proper establishment and maintenance of law and order, sound political system, sound, stable and efficient transport and communication system, efficient agricultural programme for both large, small and medium farmers and for both the rainy and dry season farming, efficient exploitation and harnessing of human and material resources, good water supply and sanitation provisions, efficient and effective alternative power supply, conducive atmosphere for commerce and investments and sound educational system. These are the basis upon which sustainable development is built and no matter how developed or advanced a state is, its development revolves around those. In states like Nigeria, most development projects started are not completed, while new and mostly duplicated or irrelevant development projects are being initiated on daily basis. Structurally, the future, stability and sustainability of the world is tied to and is interdependent on parts of the world with population growth, explosion or pressures and the other developed nations to balance development, resource allocation and management for the world to be a developed and sustained place or all.

\subsection{Issues before the Nigeria 2018 National Population and Housing Census}

Like the previous Censuses conducted in Nigeria, the future census exercise is not devoid of both general and peculiar challenges, which will ultimately determine the conduct and success or failure of the exercise.

\subsection{Census Result Controversies}

Conducts of censuses are often controversial in many states and societies of the world, especially in relation to sensitive issues of ethnicity, religion, exclusion, and politics of constituencies and resource allocations (Idike \& Eme, 2015). In the same vein, census conducts, results submission and acceptance in Nigeria have in the history been accompanied by controversies, because of its importance as a tool used by politicians to achieve respective political 
interests, hence, the issues of population and politics are very dangerous in Nigeria (Mosher, 2017; Gupte, 1994:44; Kurfi, 2004; Shagari, 2001; Brandler, 1991; Mohammed, Aisha \& Saidu, 2018). Most of the controversy, however, revolves around the self-centred interests on election as a game of number, revenue/resource allocation based on population, political power and its control, and ethno-religious manipulations.

\subsection{Funding, Transparency and Accountability}

It is noted by Nwaimo (2009:626-7) that census encompasses problems which have to do with funding, transportation and logistics, illiteracy, cultural and customs provisions and limitations, as well as political influences. The issues of transparency and accountability are key to the success of the future census exercise. This is in view of the fact that corruption which is Nigeria's major problem, is no longer abnormal to Nigeria and Nigerians as a (voluntarily or involuntarily) part of their daily life and in both public and private spheres (Aluko, 2006; Ojo 2006:267; Kalu \& Osibanjo, 1991:1; Orji, 2008:27). Most Nigerians including the census officials have a common belief that periods of census exercise are for money making in view of the fact that Federal Government sinks a lot of money, the States and Local Governments' support, while international organisations also provide counter-part funding, etc., worth millions of dollars, thus a free ride and therefore, try to grab their share and find their way. This is as such opportunity comes only decennially. Conducting censuses had similarly been very expensive for Nigeria and with the level of corruption in Nigeria and the fact that a lot of resources and logistics are to be used for the exercise. Adequate funding and proper management of same remains a major challenge in view of both the level of corruption on one hand, and shortage of the funds on the other.

\subsection{Ethno-Religious/Regional Factor, fear and Manipulation}

Ethno-religious factor has for long been very influential in the affairs of man and as noted by Yinger (1994:225) that there exists a close connection between religion and ethnicity, and as such, ethnic and religious issues can hardly be analysed without the other, but it is more pronounced where a people have a deep feeling of attachment to their ancestors. In Nigeria, the issues of religion and ethnicity have remained thorny in the conduct of census exercises and have marred the popularity and legitimacy of such exercises (Iwuoha, 2017). As manifested in previous censuses, especially 1962/63, ethno-religious actors are bound to surface again, especially with politicians who are bent on using it as an avenue to achieve their subjective ends. Similarly, during the previous censuses, there were fears from all the major tribes (Hausa/Fulani, Igbo and Yoruba) over domination of one/two by the others and also fear of regional domination among East, North and the West. This had in the 1960's partly led to the collapse of the Balewa government and democracy (see also Ademoyega, 1981; Aneke, 2007; Brandler, 1993:232; Clark, 1991; Kurfi, 2004, Mainasara, 1982; Shagari, 2001). The issues revolve around which tribe/religion has the highest number in order to dominate, influence of command more power, access and resources. The issue of population rivalry still persists today, especially for political manipulation, especially between the North as a whole and South-East and this must therefore, be properly addressed before the 2018 Census exercise.

\subsection{Politics of Constituencies and Revenue Allocation}

One of the major problems associated with the census in Nigerian is that of manipulation for revenue allocation and this has been a major challenge to many other states (Neuman, 2006; Azinge \& Udombana, 2012:163; Rimi as cited in Onu, 1981:90). It is similarly noted by Akpata (2000:24) that every party to the disagreement on revenue allocation argues from its own and most convenient points of convenience. This has typically characterized the politics of and controversy on resource control/allocation in Nigeria to the extent that it is threatening the unity and corporate existence of the Nigerian state. This time the Census is coming on the heat of the clamour for politico-geographic restructuring and resource control, economic recession in Nigeria, with several threats to declare the oil-rich Niger Delta a sovereign state under the platform of militancy in the region. These are also enveloped in the politics of insurgency, revenue allocation and the militancy, which may likely be used during the conduct of the exercise as tools to achieve some other ends, but would threaten the success of the exercise. There is also the staking issue of possible manipulation by politicians in anticipation of political constituencies' creations, allocations and revenue allocation.

\subsection{Effective Awareness and Mobilisation}

The entire success of every public exercise is substantially dependent upon the awareness it receives from the general public who are the subject. Indeed a major exercise such as population and housing census cannot achieve any meaningful success if adequate and timely mobilization is not made. The major media with which this can be achieved many and their use is dependent upon the particular category of subject targeted, but key among them are the radio and television which are easily listened and viewed by many whether rural or urban areas. But the means and mode to be used have a significant impact on the entire exercise as only positive and objective awareness and mobilisation would yield the objectives and desired results of the exercise. The types and pattern of mobilisation and awareness should themselves be regulated by authorities in terms of context, content and also quality. This is simply because census is an exercise surrounded by ulterior controversial, conflicting and selfish interests which stakeholders may manipulate it to 
achieve perceived interests, eliminate rivals, inflate/deflate figures or some reasons, include or exclude one area or the other all for other interests.

Conduct of census exercises in Nigeria have been characterised by sensitive legal battles, political instability and controversies which had led to the 1962/63 census crisis and legal battle, which extended to the January, 1966 coup, the 1973 census cancellation, and various political manipulations among others. Nigerians have gone further and advanced in the manipulation of interests on religious, social, ethno-regional and other avenues, thus the need for effective regulation of the mobilisation and awareness processes and content in order to achieve the desired results of such exercise. The social media, which is a recent development, can also be used to target the literate, remote and near population, where there are more facilities, especially those of communication. Musicians can also be used and through songs, many people, especially the youth can be reached and captured in the exercise.

\subsection{Proper Data Collection and Management}

Census is a very crucial and scientific exercise, which requires comprehensive demarcation and enumeration of areas and people, tabulation and validation of the data accepting error margin of 5\% as there can hardly be a $100 \%$ perfect Census exercise. Although it is sometimes criticised, for long and all over the world, population and housing census has been the most dependable means of gathering reliable demographic/statistical data, especially in the developing states. This places strategic importance to proper collection, effective and efficient management of data from the future census exercise in Nigeria. There is the challenge of proper gathering/collection and management of the census data both during and after the exercise (Moser \& Kalton, 2017). Hence, it is critical that the data to be gathered from the field should be properly collected and managed. Therefore, all the data to be gathered from the field should be safely handled and only by the competent personnel/authority. With the advancement in information and communication technology, there more opportunities for optimal gathering, storage/management and administration of the census data, but the process of data collection and management must only be handled by experts only, who should be additionally oriented on how to handle the census data in order to achieve the desired objectives.

\subsection{Logistics, Manpower, Timely and Adequate Preparations}

Conducting a census requires production, procurement, distribution of materials and use of huge human and material resources. It is, however, not on the D-day or shortly before the conduct of such exercise that the logistical arrangements/materials would be made or procured, but there has to be the timely provisions of adequate logistics and personnel. Those should similarly be made available and ready at the earliest practicable time in order to ensure all is set for the real exercise. This is one of the major reasons why the previous exercises encountered problems of logistics and manpower. This is associated with the Nigerian factor of 'following shortcuts and fire brigade approach' in handling matters. This, if not properly handled may result in incomplete, inaccurate, unreliable or cocked data, which may in the end render such an expensive exercise poor or invalid. Hence the challenge of provision of adequate logistics and manpower, and timely preparations.

\subsection{Sensitive Questions}

In every conduct of population and housing census all over the world, there are certain sensitive questions which affect and determine the outcome and reliability of the exercise and these relate to religion, ethnicity and race, among others (Doxsey-Whitfield, MacManus, Adamo, Pistolesi, Squires, Borkovska, \& Baptista, 2015; DellaPergola, 2018; Hackett, Stonawski, Potančoková, Grim \& Skirbekk, 2015). Socio-societal, ethno-religious factors do influence the type and nature of questions to be asked, especially the 'secondary questions', and there may easily be negative or chauvinistic interpretations of the questions, which may result in invalid, unreliable results. At this time when ethnoreligious rivalry, negative sentiments based on religion, ethnicity, tribal and other tendencies have been bred in the minds of many Nigerians, it is very important for the Nigerian authorities/census administrators to limit and properly handle all the variables (questions), especially the sensitive ones be administered during the exercise. The way and manner the questions are to be structured and presented/asked mean a lot in shaping the thinking and responses of the target population.

\subsection{Issues of Refugees/Internally Displaced Persons (IDPs), and Destroyed Houses}

Weller and Bouvier (1992:316) have noted that one of the major problems of population census all over the world is refugees which have been growing significantly and all over the world. A major problem that will be faced by the census officials in many parts of Nigeria is that of refugees and internally displaced persons either because of the insurgency in the North-East or ethno-religious crises prevalent in most parts of the country. Specifically, the wave of insurgency (Boko Haram), which has hit the North-Eastern part of Nigeria since 2009, and other ethno-religions crises across are some of the major challenges and threats to the success of the 2018 Census exercise. With over 1.3 million displaced persons due to insurgency in the states of Borno, Adamawa, Yobe states, over $3 \mathrm{~m}$ refugees scattered in the North-Eastern Nigeria and Lake Chad Region (Niger, Cameroon and Chad with over 800, 000 children as provided by the National Emergency Management Agency, NEMA, (2015 \& 2016). The issue of reaching these persons and 
enumerating them is a big challenge, although quite a number of them are temporarily settled in various IDP camps, the other hundreds of thousands are wandering the streets in search of food, menial jobs on the daily basis, with no signs of going back to their original habitats in the near future, or are trapped in remote areas. This is in addition to the ever growing number of migrants and others fleeing the Fulani/herdsmen-farmers conflict prevalent in the North Central Nigeria, which has also rendered thousands homeless. Similarly, since the census involves housing, there is the need for special consideration to the houses destroyed and or under rehabilitation in the conflict ridden/insurgency affected areas for such also form an integral part of census exercise (Meyer, Mok \& Sullivan, 2015). Indeed, tens of thousands of houses and other buildings have been destroyed in the conflicts/insurgency all over Nigeria and many of which are abandoned.

\subsection{Appointment and Recruitment of Census Officials and Enumerators}

One area of strategic importance and a cause of scam is that of recruitment and appointment of census officials and enumerators. Past experiences, especially the 2006 exercise have raised several questions when and who are to be appointed/recruited and by whom in such future exercises. There are indeed enough and qualified manpower all over the country to undertake the exercise to its rational conclusion, but the major problem remains selfish interest, which has characterised virtually all facets of Nigerians lives. Issues of special list, omitted names, Oga's list, list from the above, supplementary list, replacement list, substitution list, etc., have remained a threat for every appointment and selection in Nigeria to which Ayuba (as cited Arase \& Iwuofor, 2007:312) has decried that it is very hard or impossible to achieve the righteous in such situations. Diamond (1996:78), Joseph (1987), Obasanjo and Mabogunje (1992), Fagge (2002:89-90), Jacob \& Abdullahi (2007:65), Akpata (2000:74) have all lamented how god-fatherism, patron-client relations, opportunism, prebendalism, tribalism and freedom to buy/secure offices/appointments, favours have, at the expense of merit characterised and marred almost all processes of appointments and selections in Nigeria. As tens of thousands of people are to be appointed as ad hoc staff, there must be a strong, transparent and timely set mechanism for such recruitments and appointment with substantive criteria otherwise the exercise could be marred by few elements bent on selfish and corrupt interests. Such elements are there hidden within the system and determined to make scam out of the forthcoming exercise. A substantive and transparent means of recruitment and appointment of the census officials and enumerators are indispensable to the success of the exercise.

\subsection{Summary, Conclusion and Recommendations}

Conducting decennial population and housing census is an indispensable part of Nigeria's socio-economic, political and sustainable development. Although it has been missed at some times in Nigeria's census history and is not devoid of challenges, the census objectives can only be achieved when reliable statistical data is properly collected and analysed, and the statistical figures properly managed by the relevant authorities, and then on transmitted to other stakeholders in Nigeria's development drive. Such exercises have in the past been characterised by poor collection, controversy in acceptance, corruption, and undue or excessive politicisation. This time for the 2018 exercise, there are more challenging threats to the exercise as prevailing ethno-religious rivalry, conflicts and manipulation all over Nigeria, issues of accessibility to some parts of the North-East, North Central and the Niger Delta areas, tens of thousands of refugees and internally displaced persons across the country, threats of secession, issues of adequate funding and timely preparations, as well as logistics have necessitated the shift of the exercise earlier scheduled for the year 2016 to 2019, and are great threats to the success of the exercise, and so much have to be done therefore, to ensure its success. Sustainable development, which population census is an integral part of, has been marred in Nigeria due to poor statistical data collection, management and political will to execute plans. The forthcoming National Population and Housing Census is, indeed, a unique opportunity for Nigeria and Nigerians to use the properly collected and managed statistical results to achieve the much desired sustainable development.

\subsection{Recommendations}

The Nigerian government should fully involve and join hands with the private sector for all necessary support, especially in terms of funding and logistics in the future census exercise. Nigeria should shift from physical counting and opt for administrative census using and harmonising all available data banks of Bank Verification Numbers (BVN), National Identity Card, Tax Identification Number (TIN), Voters Registration Card, Drivers' Licenses, SIM Card Registration records, etc., which are all sources of administrative data that are safer and more accessible, which inexpensive, more reliable and can also easily replace the resource intensive physical head counting. All avenues of creating awareness for the exercise, especially radio for the rural and remote areas and over the social media for the urban areas to ensure and achieve intensive and extensive awareness should be used. Religious, cultural institutions and organisations should be coopted to ensure full mobilisation and participation of their members towards the success such the exercise. All preparations (budget, recruitments, appointments, time, logistics, etc.) should commence in advance so as to meet the target. All sensitive questions should be fully resolved and properly set so as to avoid any form of sentiments/fear/mistrust, etc., during the exercise. Resources to be used for the exercise should be fully utilised, monitored and accounted for in order to reduce the extent of corruption and mismanagement of public resources. 
Adequate security should be provided for both the target population, census officials and the enumerators especially in volatile areas such as North-East, Niger Delta, Benue and Plateau States. All security agencies should be on alert to crush any attempt to thwart the exercise, especially from the areas hit by the insurgency, the Igbo South-East Biafran agitators, and parts of the South-South where there has been militant. All the relevant authorities and stakeholders to be involved in the exercise should ensure that as much transparency as possible is demonstrated so as to avoid any doubt, manipulation of figures, suspicion or controversy during the exercise. The Federal government of Nigeria should take bold and strict steps to ensure proper management and dissemination of the census data to protect it from all bad elements, hackers and any possible damage/manipulations. All the powers conferred on the National Population Commission should be strictly exercised in accordance with Sections 153 (1j), 158 (2a-d) and Third Schedule, Part I (J23) of the 1999 Constitution of the Federal Republic of Nigeria so as forestall any conflict or controversy during the exercise, final figures declaration and acceptance. The processes and requirements for selection, recruitment and appointment of all census enumerators and officials should be clearly set out and conducted in the most meritorious and transparent ways in order to avoid scams of appointments and selections which have characterised the last census exercise in Nigeria.

\section{References}

Adele, J. (2009). Falsification of population census data in a heterogeneous Nigerian state: The fourth republic example. African Journal of Political science and International relations, 3(8), 311-319.

Ademoyega, A. (1981). Why we struck: The story of the first Nigerian coup. Ibadan: Evans Brothers Publishers.

Adeniyi, F. O. (1981). Housing the urban masses in Nigeria. The Nigerian Journal of Development Studies, 1 (2), 37 48.

Ajayi, O. KJW. (2009). Nigeria: Africa’s failed asset. Ibadan: BookCraft.

Akpata, T. (2000). In pursuit of nationhood: Selected writings on politics in Nigeria. Lagos : Malthouse Press Limited.

Allison, A. (1970). Population control. Middlesex-England: Penguin Books.

Aluko, J. O. (2006). Corruption in the Local Governments in Nigeria. Ibadan: Book Builders.

Amuwo, K, Agbale, A., Suberu, R., \& Herault, G. (1998). Federalism and political restructuring in Nigeria. Ibadan: Spectrum Books.

Aneke, L. N. (2007). The Untold story of the Nigeria-Biafra war. New-York: Triumph Publishing.

Arase, E. S. \& Iwuofor, I. P. O. (eds.). (2007). Policing Nigeria in the 21st Century. Ibadan: Spectrum Books.

Ate, B. E., \& Akinterinwa, B. A. (1992). Nigeria and its immediate neighbours: Constraints and prospects of Sub regional security in the 1990s. Lagos: NIIA and Pumark Nigeria.

Ayida, A. A. (1987). Reflections on Nigeria’s development. Ibadan: Heinemann Educational Books.

Azinge, E., \& Udombana, N. (2012). Drafting legislation in Nigeria: Constitutional imperatives. Lagos : Nigeria Institute of Advanced Legal Studies.

Brandler, J. L. (1993). Out of Nigeria: Witness to a giant's toils. Ibadan: Spectrum Books.

Clark, T. (1991). A Right Honourable Gentleman - The life and times of Alhaji Sir Abubakar Tafawa Balewa. Zaria: Huda-Huda Publishing Company.

Coleman, J.S., \& Roseberg, C.G. (eds.). (1970). Political parties and national integration in tropical Africa. Berkeley: University of California Press.

Della Pergola, S. (2018). Ethno-religious intermarriage in Israel: an exploration of the 2008 census. Journal of Israeli History, 1-22.

Diamond, L. (1996). Towards Democratic Consolidation. Journal of Democracy, 7(3), 33-48. 
Doxsey-Whitfield, E., MacManus, K., Adamo, S. B., Pistolesi, L., Squires, J., Borkovska, O., \& Baptista, $\quad$ S. $\quad$ R. (2015). Taking advantage of the improved availability of census data: a first look at the gridded population of theworld. Papers in Applied Geography, 1(3), 226-234.

Elaigwu, J. I., \& Garba, A. A. (2015). Green federalism - The Nigerian experience. In Chakrabarti,

P. D., \& Srivastava, N. Green federalism experiences and practices (eds., pp. 81-102). New Delhi: The Energy and Resources Institute (TERI) Press.

Fagge, K. S. (2002). Democracy in Nigeria's fourth republic: Myth, realities, challenges and prospects. Kano, Nigeria: Triumph Publishers

Fairley, W. B., \& Mosteller, F. (1977). Statistics and public policy. Massachusetts: Addison- Wesley Publishing Company.

Falola, T., \& Heaton, M. M. (2008). A History of Nigeria. London: Cambridge University Press.

Falola, T., Mahdi, A., Uhomoibhi, M., \& Anyanwu, U. (1991). History of Nigeria 3. Lagos: Longman Nigeria Plc.

Gupte, P. (1984). The crowded earth: People and the politics of population. General Ontario: Publishing Company.

Himmelfarb, M., \& Baras, V. (eds.). (1978). Zero population growth - for whom: A differential fertility and minority survival. Connecticut: Greenwood Press.

Hosh, D. K. (1993). Business policy, strategic planning and management. New York: Suition Chand \& Sons Publishers.

Idike, A., \& Eme, O. I. (2015). Census politics in Nigeria: an examination of 2006 population census. Journal of Policy and Development Studies, 289(1851), 1-26.

Iwuoha, C. M. A (2017). Religious plurality and ethnicity: A bane to population census in Nigeria. International Journal of Current Innovation Research, 3(8) 733-737.

Jacob, J., \& Abdullahi, A. (2007). The legislature, economic reforms and democracy in Nigeria : An assessment. Journal of Legislative Studies. 1(1)1-17.

Joseph, R. A. (1987). Democracy and prebendal politics in Nigeria: The rise and fall of the second republic. Ibadan: Spectrum Books.

Kalu, A. U. \& Osibanjo, Y. (eds.) (1991). Perspectives on corruption and other crimes in Nigeria. Lagos : Federal Ministry of Justice.

Kirk-Greene, A. H. M. (Ed). (1971). Crises and conflict in Nigeria: A documentary source book 1966-1970. London: Oxford University Press.

Kurfi, A. (2004). My Life and Times (an autobiography). Ibadan: Spectrum Books Limited.

Kwanashie, G.A. (2002). The making of the north in Nigeria. Kaduna: Ahmadu Bello University Press.

Lele, S. M (1991). Sustainable development: A critical review. World Review. 19(6) 607- 621.

Lipsey, R. G. \& Chrystal, K. A. (1995). An Introduction to positive economics. London: Oxford University Press.

Lutz, W. (ed.). (1994). The future of population of the world: What can we assume today? London : Earthscan Publications.

Mainasara, A.M. (1982). The Five Majors: Why they struck. Zaria: Hudahuda Publishing Company.

Mason, K. A., Losos, J. B. \& Singer, S. R (2011). Biology. New York: McGraw-Hills Company. 
McConnell, C. R (1987). Economics: Principles, problems, and policies. Boston: McGraw-Hill Irwin.

McEarchern, W. A. (1994). Micro Economics: A Contemporary Introduction. Ohio: South-Western Publishing Co.

Miller, G. T. (2007). Living in the environment: Principles, connections, and solutions. Belmont, CA : Brooks/Cole Cengage.

Miller, G. T. Jr. \& Spoolman, S. (2008). Environmental sciences: Principles, connections, and solutions. Belmont, CA: Brooks/Cole Cengage.

Mohammed, I. S. \& Aisha, A. A. (2018). Fulani/herdsmen-farmers conflict in Nigeria: The emerging dimensions, complications and the theatre. Beau Bassin, Mauritius: Lambert Academic Publishing.

Mohammed, I. S. (2018). Post Boko Haram insurgency, Nigeria's national security and emergent threats. Journal of humanities and cultural studies R\&D, 3(2), 1-15.

Mohammed, I. S., Aisha, A. A., \& Saidu, A. (2018). Nigerian political development. Beau Bassin, Mauritus: Lambert Academic Publishing.

Mosher, S. (2017). Population control: Real costs, illusory benefits. New York, NY: Routledge.

Moser, C. A., \& Kalton, G. (2017). Survey methods in social investigation. New York, NY: Routledge.

Moss, R. P. \& Rathbone, R. J. (eds.). (1975). The population factor in African studies. London : University of London Press.

National Bureau of Statistics (NBS). (2018). Multi-indicator cluster Survey 2016-2018 survey finding report. Abuja, Nigeria: NBS

National Emergency Management Agency (NEMA) Report, December, 2015. Abuja, Nigeria

National Emergency Management Agency (NEMA) Report, July, 2015. Abuja, Nigeria

Nnoli, O. (1978). Ethnic politics in Nigeria. Enugu-Nigeria: Fourth Dimension Press.

Nwaimo, C. E. (2009). Applied principles of economics. Owerri - Nigeria: Supreme Publishers.

Obasanjo, O. \& Mabogunje, A. (eds.). (1992). Elements of democracy Abeokuta: Africa Leadership Forum.

Ogunbameru, K. A. \& Rotimi, W. R. (2006). Man and his social environment. Ibadan: Spectrum Books.

Ojo, E. O. (ed.). (2006). Challenges of sustainable democracy in Nigeria. Ibadan: John Archers Publishers.

Okafor, S. O. (2015). Misconception of population census and vital registration in Nigeria: A factor in socio economic and political stagnation. In Conference Proceedings, 20th-22nd October 2015, University of Nigeria, Nsukka.

Onu, E. (ed.). (1981). Struggle for redemption: Selected speeches of Muhammad Abubakar Rimi. Zaria : Northern Nigeria Publishing Company.

Orewa, O. G. (1997). We are all guilty: The Nigerian Crisis. Ibadan: Spectrum Books.

Orji, J. I. (2008). New approaches to effective poverty alleviation in Nigeria. Kaduna: Joy Graphics Printers and Publishers.

Oyeshola, D. P. O. (2008). Sustainable development: Issues and challenges for Nigeria. Ibadan: Daily Graphics Nigeria.

Oyovbaire, S. E. (1979). The theory of federation: A critical appraisal. Nigerian Journal of Political Science. Zaria: Ahmadu Bello University. 
Paden, J. N. (1986). Values and Leadership in Nigeria. Ahmadu Bello Sardauna of Sokoto. Zaria: Huda-Huda Publishing Company.

Peterside, S. J., Bassey, E. \& Goyo, N. (eds.) (2010). Domestication of Extractive Industries Transparency Initiative (EITI) in Nigeria : Gaps between Commitment and Implementation. A Civil Society Assessment of the Performance of Nigeria Extractive Industries Transparency Initiative (NEITI). Abuja: CISLAC.

Ross, C. A. Forsyth, D. \& Huq, M. (2009). Development economics. London: McGraw-Hills Higher Education.

Samuelson, P. A., \& Nordhaus, W. A. (2005). Economics. New York: McGraw-Hill Companies.

Shagari, S. (2001). Shehu Shagari: Beckoned to serve (an autobiography). Ibadan: Heinnman Educational Books.

Shehu, I. M., Othman, M. F. B., Osman, N., B., (2017). Ethno-religious and regional rivalry in Nigeria: An old and creeping trend Asian Journal of Multidisciplinary Studies, 5(5), 14-23.

Simon, J. L. (1981). The Ultimate resource. Oxford: Princeton University Press.

Som, A. (2008). Innovative Human resources management and corporate performance in the context of economic liberalisation in India. Thunder bird International Business Review, 49(2), 55 - 67.

Starr, C., Evers, C. A., \& Starr, L. (2010). Biology: Today and tomorrow with physiology. Belmont, C A: Brook/Cole, Cengage Learning.

The Report of the Political Bureau. (1987). Lagos, Nigeria: National Directorate of Social Mobilisation.

The World Bank. (1984). Population changes and economic development. London: Oxford University Press.

Uchegbu, S. N. (1998). Environmental management. Enugu: Precision Printers \& Publishers.

United Nations Organisation. (1958). Principles and Recommendations for National Population Censuses. New York: United Nations.

Uwuche, R., Bing, A., Derrick, J., Owino, P. A. \& Matatu, G. (eds.). (1991). Africa today. London: Africa Books.

Weller, R. H. \& Bourvier, L. F. (1992). Population: Demography and policy New York, NY: St. Martins Press.

Whitaker, C. S. (1970). The politics of tradition: Continuity and Change in northern Nigeria. Princeton, New Jersey: Princeton University Press.

Yinger, M. (1994). Ethinicity. New York: State University Press.

Young, C. (1979). The politics of cultural pluralism. Ibadan: Heinemann Educational Books.

Meyer, B. D., Mok, W. K., \& Sullivan, J. X. (2015). Household surveys in crisis. Journal of Economic Perspectives, 29(4), 199-226.

Hackett, C., Stonawski, M., Potančoková, M., Grim, B. J., \& Skirbekk, V. (2015). The future size of religiously affiliated and unaffiliated populations. Demographic research, 32, 829-842. 